\title{
Modification of sensitivity of food intake to $\beta 2$-agonist by bovine somatotropin in dry and lactating dairy cows
}

\author{
N Bareille, P Faverdin, M Hay \\ INRA, Station de Recherches sur la Vache Laitière, Saint-Gilles, 35590 L'Hermitage, France
}

In early lactation, the dairy cow reaches maximum food intake after peak lactation and mobilizes lipids from adipose tissues. Several explanations exist for this limitated appetite, including its hormonal profile. Furthermore, $\beta$ agonists are known to stimulate lipolysis and reduce dry matter intake (DMI). The objective of this experiment was to show whether growth hormone could enhance $\beta 2$-adrenergic effect on both appetite and lipomobilization.

Two groups of four Holstein cows were used in a crossover design experiment. The first group was composed of lactating cows $(28.5 \mathrm{~kg} / \mathrm{d}$ of milk) and the second one of non-pregnant (except one) dry cows for which bST treatment could not increase energy requirements. Treatments consisted of daily injections of 40 mg bST (Elanco - Eli Lilly Co, Grienfield, USA) or excipient (BST vs CTRL). Periods lasted 13 days and were separated by a 8-day readjustment interval. Clenbuterol (13.3 $\mathrm{ng} / \mathrm{kg} / \mathrm{min}$ for 4 hours) or saline intravenous challenges (Clen vs sal) were administrated either on day 8 or 11 of each period. They were performed in the morning during the main meal (08:00 to 12:00). Response on food intake was continuously recorded while metabolic parameters were monitored for 48 hours after challenge. Dairy cows were fed a mixed diet of dehydrated whole crop maize $(60 \%)$, dehydrated lucerne $(20 \%)$ and concentrate $(20 \%)$ and was offered ad libitum twice daily for four hours at 08:00 and 18:00 hours. Data were analysed with three contrasts : C1 (with CTRL, clen vs sal) ; $\mathrm{C} 2$ (with BST, clen vs sal) ; $\mathrm{C} 3$ (C1 vs C2).

In lactating cows, clenbuterol reduced DMI on the day of perfusion, mainly on the evening meal. BST potentialised clenbuterol action that appeared 3 hours after the initiation of perfusion and remained significant during two days. BST enhanced clenbuterol-induced lipolysis during perfusion (plasma FFA increase of +930 vs $+100 \mu e q / I)$ and hyperglycemia (plasma glucose increase of $+31 \mathrm{vs}+15 \mathrm{mg} / 100 \mathrm{ml}$ ). Lactating cows increased milk production $(+6.7 \mathrm{~kg} / \mathrm{d})$ and they were in negative energy balance contrary to dry cows. Intake and metabolic parameters with clen/CTRL and clen/BST were modified with the same intensity in both lactating and dry cows.

The results showed that bST per se, and not through an increase of energy needs, enhances $\beta 2$-adrenergic response on both lipolysis and food intake. In early lactation, growth hormone is known to increase milk production and stimulate lipolytic activity of adipose tissue, and it could also limitate appetite in order to elicit adaptations necessary to reach maximum DMI.

\begin{tabular}{|c|c|c|c|c|c|c|c|}
\hline \multirow[b]{2}{*}{$\mathrm{DMI}(\mathrm{kg} / \mathrm{d})$} & \multicolumn{2}{|c|}{ CRTL } & \multicolumn{2}{|c|}{ BST } & \multirow[b]{2}{*}{$\mathrm{C} 1$} & \multirow[b]{2}{*}{$\mathrm{C} 2$} & \multirow[b]{2}{*}{$\mathrm{C3}$} \\
\hline & Saline & Clenbuterol & Saline & Clenbuterol & & & \\
\hline \multicolumn{8}{|c|}{ Lactating cows } \\
\hline Day 1 & 23.0 & 20.6 & 22.2 & 16.3 & NS & $* *$ & NS \\
\hline Day 2 & 23.6 & 22.5 & 22.4 & 19.2 & NS & * & NS \\
\hline \multicolumn{8}{|l|}{ Dry cows } \\
\hline Day 1 & 12.4 & 10.6 & 11.4 & 4.7 & NS & * & NS \\
\hline Day 2 & 14.6 & 13.5 & 13.0 & 7.8 & NS & $* *$ & * \\
\hline
\end{tabular}

NS : non significant ; ${ }^{\star}: \mathrm{P}<0.05 ;{ }^{* \star}: \mathrm{P}<0.01$ 